\title{
Proteomic responses to silver nanoparticles vary with the fungal ecotype
}

\author{
Diana Barros $^{\mathrm{a}, \mathrm{b}}$, Arunava Pradhan ${ }^{\mathrm{a}, \mathrm{b}, *}$, Cláudia Pascoal ${ }^{\mathrm{a}, \mathrm{b}}$, Fernanda Cássio ${ }^{\mathrm{a}, \mathrm{b}}$ \\ ${ }^{a}$ Centre of Molecular and Environmental Biology (CBMA), Department of Biology, University of Minho, Campus of Gualtar, 4710-057 Braga, Portugal \\ ${ }^{\mathrm{b}}$ Institute of Science and Innovation for Bio-Sustainability (IB-S), University of Minho, Campus of Gualtar, 4710-057 Braga, Portugal
}

\section{H I G H L I G H T S}

- Effects of AgNPs and $\mathrm{Ag}^{+}$on fungi from clean and metal-polluted streams were tested.

- AgNP effects on growth showed higher tolerance of the ecotype from polluted stream.

- AgNPs induced stress-responsive proteins and activities of antioxidant enzymes.

- Proteomics revealed diverse biological pathways in ecotypes induced by each $\mathrm{Ag}$ form.

- Dissolved $\mathrm{Ag}^{+}$released from AgNPs had a minor role in AgNP toxicity.

\section{A R T I C L E I N F O}

\section{Article history:}

Received 6 September 2019

Received in revised form 3 November 2019

Accepted 3 November 2019

Available online 23 November 2019

Editor: Damia Barcelo

\section{Keywords:}

Silver nanoparticles

Fungal ecotypes

Polluted and non-polluted streams

Proteomics

Antioxidant enzymes
G R A P H I C A L A B S T R A C T

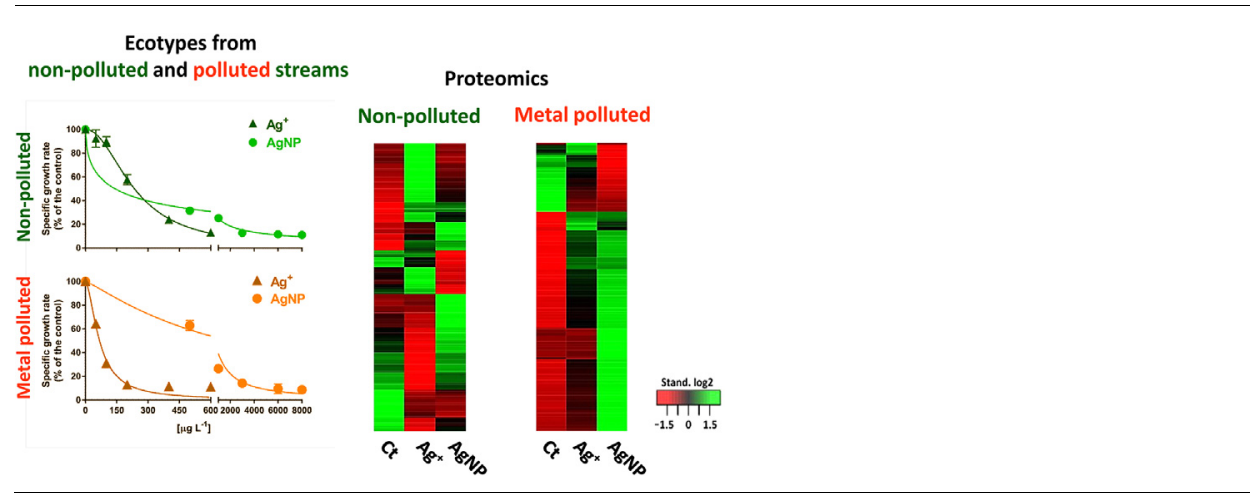

\begin{abstract}
A B S T R A C T
Enhanced commercial application of silver nanoparticles (AgNPs) is increasing the chance of their release into aquatic environments, potentially putting non-target microorganisms at risk. Impacts of AgNPs and $\mathrm{Ag}^{+}$on two fungal ecotypes of Articulospora tetracladia, collected from a metal-polluted (At61) and a nonpolluted (At72) stream, were assessed based on antioxidant enzymatic and proteomic responses. At61 showed more tolerance to AgNPs than At72 ( $\mathrm{EC}_{20}, 158.9 \mathrm{vs} 7.5 \mu \mathrm{g} \mathrm{L}^{-1}$, respectively). Antioxidant enzyme activities were induced by $\mathrm{AgNPs}$ or $\mathrm{Ag}^{+}$in both fungal ecotypes. Proteomic responses to $\mathrm{AgNPs}$ or $\mathrm{Ag}^{+}$ revealed that $41.3 \%$ of the total altered proteins were common in At72, while $27.3 \%$ were common in At61. In At72, gene ontology enrichment analyses indicated that $\mathrm{Ag}^{+}$increased mainly the content of proteins involved in proteostasis and decreased the content of those related to vesicle-mediated transport; whereas the key group of proteins induced by AgNPs had functions in DNA repair and energy production. In At61, AgNPs induced proteins involved in energy production and protein biosynthesis, while both $\mathrm{Ag}$ forms induced proteins related to cell-redox and protein homeostasis, ascospore formation, fatty acid biosynthesis and nucleic acids metabolism. Both $\mathrm{Ag}$ forms induced stress-responsive proteins, and this was consistent with the responses of antioxidant enzymes. The negligible quantity of $\mathrm{Ag}^{+}$released from AgNPs $\left(<0.2 \mu \mathrm{g} \mathrm{L}^{-1}\right)$ supported a minor role of dissolved ionic form in AgNP-induced toxicity to both fungal ecotypes. Overall, results unraveled distinct mechanisms of toxicity and cellular targets of nanoparticulate and ionic silver in aquatic fungi with different environmental background, and constitutes a proof of concept that toxicants induce adaptive responses in microbes to face emergent contaminants.
\end{abstract}

(c) 2019 Elsevier B.V. All rights reserved.

\footnotetext{
* Corresponding author at: Centre of Molecular and Environmental Biology (CBMA), Department of Biology, University of Minho, Campus of Gualtar, 4710-057 Braga, Portugal.

E-mail address: arunava@bio.uminho.pt (A. Pradhan).
}

\section{Introduction}

Silver nanoparticles (AgNPs) are among the most widespread engineered nanomaterials because of their various applications 
such as in cosmetics, electronics, textiles, biomedicals and pharmaceuticals (Blaser et al., 2008; Vance et al., 2015; Burdușel et al., 2018). The global production of AgNPs was estimated to be 20500 tons annually (Mueller and Nowack, 2008; European Commission, 2012). About 25-30\% of the marketed AgNPs are predicted to be discharged and to reach freshwaters, with potential risks to biota and the processes they govern (Blaser et al., 2008; Kaegi et al., 2010). The predicted environmental concentrations of AgNPs in surface waters range between $10^{-3}$ and $10^{-1} \mu \mathrm{g} \mathrm{L}^{-1}$, but higher concentrations can be found in runoffs from wastewaters, outdoor facades or accidental spills (Mueller and Nowack, 2008; Kaegi et al., 2010; Gottschalk et al., 2013).

AgNPs can exhibit adverse impacts on freshwater organisms, including algae, bacteria, fungi, nematodes, cladocerans and fishes (Navarro et al., 2008; Pradhan et al., 2011; Gottschalk et al., 2013; Barros et al., 2019). However, the complexity of the AgNP effects in natural environments has limited the establishment of welldirected and species-specific toxicity assessment guidelines. Interaction of nanoparticles with living organisms depends on several factors, including particle size, shape and aggregation (Bai et al., 2017), with implications to nanoparticle toxicity (Akter et al., 2017). Moreover, the mode of toxicity of AgNPs remains unclear, as some studies suggest that the toxicity can be related to speciation of the dissolved $\mathrm{Ag}^{+}$from nanoparticles (Navarro et al., 2008; Behra et al., 2013), while others have shown direct toxicity of AgNPs (Tlili et al., 2016). AgNPs may induce oxidative stress in aquatic organisms, consequently damaging the cellular macromolecules such as proteins, lipids and DNA (He et al., 2012; van Aerle et al., 2013). Activities of antioxidant enzymes, such as superoxide dismutase (SOD), catalase (CAT), glutathione peroxidase (GPx) and glutathione S-transferase (GST), are considered early warning biomarkers of oxidative stress induced by ionic and nanoparticulate forms of metals in freshwater organisms (Pradhan et al., 2015, 2016; Barros et al., 2019). Most of these antioxidant enzymes belong to the ascorbate-glutathione cycle and play crucial roles in regulating cellular redox homeostasis and preventing cellular damage (Ayer et al., 2014).

The advancements in proteomics have allowed the identification of proteins as potential stress biomarkers and paved the way to reveal mechanisms of action of environmental contaminants (Santos et al., 2009; Barros et al., 2019). Several studies on the cellular stress response and functional proteins have shown that there is a convergence towards a common set of stress-induced proteins in widely diverse taxa (Petrak et al., 2008; Wang et al., 2009). Therefore, application of enzymatic stress biomarkers and proteomics might be a useful approach to reveal the mechanisms of AgNP toxicity (Barros et al., 2019).

Aquatic fungi play a key role in organic matter decomposition in trophic networks in streams (Pascoal and Cássio, 2008). Although these fungi are generally sensitive to water quality, they occur in metal-polluted streams probably because they are able to develop specific adaptive responses (Azevedo et al., 2009; Pradhan et al., 2015). However, the mechanisms underlying those adaptive responses are not clear.

The aim of this study was to investigate i) whether metaladapted aquatic fungi can exhibit tolerance to AgNPs by triggering specific molecular responses, and ii) whether those responses can vary with the metal form. We examined the impacts of AgNPs on two fungal ecotypes of Articulospora tetracladia, one collected from a metal-polluted (At61) stream and the other from a non-polluted (At72) stream. We determined i) dose-response effects on fungal growth, ii) enzymatic oxidative stress biomarker responses, and iii) proteomic responses to unravel the molecular mechanisms underlying the impacts of each Ag form to different fungal ecotypes. We hypothesized that i) the fungal ecotype from the nonpolluted stream would be more sensitive to AgNPs than the one from the metal-polluted stream, ii) the proteomic profiles would match with those of antioxidant enzymes, and iii) proteomics would reveal distinct functional responses to each form of $\mathrm{Ag}$.

\section{Materials and methods}

\subsection{Fungal ecotypes}

Two fungal ecotypes of a cosmopolitan species were used: i) Articulospora tetracladia UMB-072.01 (At72), isolated from foam at Maceira, a non-polluted stream in Peneda-Gerês National Park, Portugal, and ii) A. tetracladia UMB-061.01 (At61), isolated from decomposing leaves at a metal-polluted site of the Este River, near the industrial park of the city of Braga, Portugal. At the polluted site, the metal concentrations in the sediments were $\mathrm{Cu}$ : 518.1, Cd: 0.14 and $\mathrm{Pb}: 16.4 \mathrm{~g} \mathrm{~kg}^{-1}$ of volatile dry weight (Soares et al., 1999). Further details on sampling sites can be found elsewhere (Pascoal et al., 2005). Fungi were maintained on malt extract agar (ME, $1 \% \mathrm{w} / \mathrm{v}$; agar, $1 \% \mathrm{w} / \mathrm{v} ; 18^{\circ} \mathrm{C}$ ).

\subsection{Preparation of AgNP suspensions and $\mathrm{Ag}^{+}$solutions}

A suspension of citrate-coated AgNPs (NanoSys GmbH, Wolfhalden, Switzerland) was used to prepare the stock of AgNPs $\left(0.1 \mathrm{~g} \mathrm{~L}^{-1}\right.$ ) in sterile ultrapure water (Milli-Q $18.2 \mathrm{M} \Omega-\mathrm{cm}$ ) followed by filtration $(0.2-\mu \mathrm{m}$; Millipore, Billerica, MA, USA). The stock solution of $\mathrm{Ag}^{+}$was prepared $\left(0.1 \mathrm{~g} \mathrm{~L}^{-1}\right)$ by dissolving the $\mathrm{AgNO}_{3}$ salt (>99\%, Sigma-Aldrich, MO, USA) in sterile ultrapure water followed by filtration.

\subsection{Characterization of nanoparticles and quantification of silver}

Zeta potential $(\zeta)$ and dynamic light scattering (DLS) were used (Zetasizer Nano ZS, Malvern Instruments Limited, UK) to determine the stability, dispersity and hydrodynamic size distribution of AgNPs in malt extract medium at the beginning (T0) and end (T1) of the exposure.

Inductively Coupled Plasma Mass Spectrometer (Thermo X7 QICP-MS, Thermo Scientific) was used to quantify silver and $\mathrm{Ag}^{+}$ released by dissolution from AgNPs in the growth medium at T0 and T1 (Scientific and Technological Research Assistance Centre, University of Vigo, Spain). Fungal mycelia were removed from the medium by centrifugation $(5000 \times \mathrm{g}, 5 \mathrm{~min})$. The dissolved $\mathrm{Ag}^{+}$from AgNPs was quantified in biomass-free supernatant after ultrafiltration (3220 $\times$ g, 30 min; 3-times) using Amicon Ultra-15 centrifugal filter units ( $3 \mathrm{kDa}$ m.w. cut-off, $<2 \mathrm{~nm}$ of estimated pore size; Merck Millipore, Germany) followed by acidification $\left(\mathrm{HNO}_{3}\right.$, $1.68 \% \mathrm{v} / \mathrm{v})$. The retrieved mycelia were weighed and washed thrice with L-cysteine ( $2 \mathrm{~mL}, 0.5 \mathrm{mM}$ ) to remove the adsorbed silver as $\mathrm{Ag}^{+}$after acidification as above. Then, mycelia were soaked in 5\% $\mathrm{HNO}_{3}$, washed thrice with sterile ultrapure water and lyophilized for $48 \mathrm{~h}$. Finally, mycelia were weighed, mineralized $\left(550{ }^{\circ} \mathrm{C}\right.$, $12 \mathrm{~h})$ and digested $\left(2 \% \mathrm{HNO}_{3}\right)$ to determine the accumulated $\mathrm{Ag}$ in fungi.

\subsection{Exposure conditions and effective sublethal concentrations}

To establish the exposure concentrations for assessing the responses of proteome and antioxidant enzymes, effective sublethal concentrations (ECs) of $\mathrm{AgNPs}$ or $\mathrm{Ag}^{+}$on the growth of each fungal ecotype were determined. To that end, one agar plug (12mm diameter, 5-mm depth; MEA 1\%) of 20 day-old culture of each fungus was homogenized (Ultraturrax, IKA, Staufen, Germany) in $1 \mathrm{~mL}$ of sterilized liquid malt extract medium (ME, $1 \%$ ), and $1 \mathrm{~mL}$ of the homogenate was transferred aseptically into 250-mL Erlen- 
meyer flasks containing $100 \mathrm{~mL}$ of $1 \%$ sterile ME. After $48 \mathrm{~h}$ of fungal growth $\left(18{ }^{\circ} \mathrm{C}, 140 \mathrm{rpm}\right)$, each fungal culture was exposed to increasing concentrations of $\operatorname{AgNPs}\left(0,0.5,1,3,6\right.$ and $\left.8 \mathrm{mg} \mathrm{L}^{-1}\right)$ or $\mathrm{Ag}^{+}\left(0,0.05,0.1,0.2,0.4\right.$ and $\left.0.6 \mathrm{mg} \mathrm{L}^{-1}\right)$ in triplicates. Fungal cultures were then incubated for 3 days $\left(18^{\circ} \mathrm{C}, 140 \mathrm{rpm}\right)$ to reach mid-exponential growth phase.

For antioxidant enzymatic assays, fungal cultures at midexponential growth phase were exposed for 3 days to i) AgNPs at $\mathrm{EC}_{20}$, ii) $\mathrm{Ag}^{+}$at $\mathrm{EC}_{20}$, and iii) AgNPs at the concentrations corresponding to the $\mathrm{EC}_{20}$ of $\mathrm{Ag}^{+}$. For proteomic analysis, the fungi were exposed for 3 days to either $\mathrm{AgNPs}$ or $\mathrm{Ag}^{+}$at the respective $\mathrm{EC}_{20}$.

\subsection{Fungal biomass, preparation of mycelia-free extract and protein quantification}

For biomass quantification, fungal mycelia were harvested by filtration ( $5 \mu \mathrm{m}$; Millipore, Billerica, MA, USA), washed with Milli $\mathrm{Q}$ water, dried at $80{ }^{\circ} \mathrm{C}$ to constant mass $(48 \mathrm{~h})$, and weighed to the nearest $0.001 \mathrm{~g}$.

For preparation of mycelium-free extract, fungal biomass was harvested $\left(5000 \times g\right.$ for $5 \mathrm{~min}$ at $4{ }^{\circ} \mathrm{C}$ ), dipped in liquid nitrogen and stored at $-80{ }^{\circ} \mathrm{C}$ until used. For antioxidant enzymatic and proteomic analyses, mycelia were washed twice with $100 \mathrm{mM}$ potassium phosphate $\left(\mathrm{K}_{2} \mathrm{HPO}_{4}+\mathrm{KH}_{2} \mathrm{PO}_{4}\right.$, pH 7.4) buffer (1:8, w: v) at $4{ }^{\circ} \mathrm{C}$, and ground with liquid nitrogen in a cooled mortar. Ground mycelium was then resuspended in the extraction solution containing $100 \mathrm{mM}$ potassium phosphate buffer (pH 7.4), $2 \mathrm{mM}$ ethylenediaminetetraacetic acid and $1 \mathrm{mM}$ phenylmethylsulfonyl fluoride at $4{ }^{\circ} \mathrm{C}$ and homogenized (Ultraturrax, IKA, Staufen, Germany). Mycelium-free extracts were obtained after centrifugation of the homogenates $\left(10,000 \times \mathrm{g}\right.$ for $10 \mathrm{~min}$ at $\left.4{ }^{\circ} \mathrm{C}\right)$ followed by filtration $(0.2 \mu \mathrm{m}$; Millipore, Billerica, MA). For proteomics, the protein suspensions were concentrated (trichloroacetic acid + deoxycholate/acetone precipitation). Concentration of proteins in mycelium-free extracts was quantified based on the Lowry method (Peterson, 1983).

\subsection{Denaturation, SDS-PAGE separation and SWATH-MS of proteins}

A denaturation step was performed before identification of proteins as described elsewhere (Barros et al., 2019). Briefly, incubations (60 min, RT) of total proteins with urea loading buffer ( $9 \mathrm{M}$ urea, $50 \mathrm{mM}$ Tris, pH 8.8, $20 \mathrm{mM}$ dithiothreitol, 10\% w/v SDS, $10 \% \mathrm{v} / \mathrm{v}$ glycerol, $0.002 \% \mathrm{w} / \mathrm{v}$ bromophenol blue) were carried out consecutively in the absence and presence of $20 \mathrm{mM}$ acrylamide. This was followed by SDS-PAGE separation of proteins. The bands in the gel containing total proteins were excised, sliced into small pieces, and proteins were identified at the Center for Neuroscience and Cell Biology, University of Coimbra, Portugal.

The Sequential Windowed data independent Acquisition of the Total High-resolution Mass Spectra (SWATH-MS) setup was specifically designed (Table S1), and analyses were performed based on Barros et al. (2019). Briefly, the gel pieces were destained, washed with deionized water, dehydrated and subjected to in gel digestion (0.01 $\mu \mathrm{g} \mu \mathrm{L}^{-1}$ of trypsin) using the short-GeLC approach (Anjo et al., 2014). The formed peptides were subjected to solid phase extraction (C18 stationary phase, Agilent Technologies), and resuspended in $40 \mu \mathrm{L}$ of mobile phase containing iRT peptides (Biognosys AG) as internal standards. Triple TOFTM 5600 System $\left(\right.$ ABSciex $^{\circledR}$ ) was used for sample analyses in two phases: i) information-dependent acquisition (IDA) of the pooled sample for protein identification, and ii) SWATH acquisition of each individual sample for protein quantification. Libraries were obtained using Protein PilotTM software (v5.1, ABSciex ${ }^{\circledR}$ ) searching against the SwissProt database (released in March 2016). SWATH ${ }^{\mathrm{TM}}$ processing plug-in for PeakView ${ }^{\mathrm{TM}}$ (v2.0.01, ABSciex $\left.{ }^{\circledR}\right)$ was used to perform the SWATH data processing. Peptides ( $\leq 15$ peptides per protein with $\leq 5$ fragment ions) were chosen automatically from the library and SWATH ${ }^{\mathrm{TM}}$ quantitation was attempted for all proteins in the library file, identified $<5 \%$ local false discovery rate (FDR) from ProteinPilot ${ }^{\mathrm{TM}}$ searches, by extracting the peak areas of the target fragment ions of those peptides using an extractedion chromatogram (XIC) window of 5 min with $100 \mathrm{ppm}$ XIC width. All peptides that met 1\% FDR threshold (in at least 3 out of 4 replicates) were retained; the content of proteins were estimated by summing all the respective transitions from the filtered peptides for a given protein and normalized to the total intensity (see supporting information for details).

\subsection{Antioxidant enzyme activities}

The activities of antioxidant enzymes were measured in mycelium-free extracts from fungi exposed to AgNPs or $\mathrm{Ag}^{+}$using a microplate reader (SpectraMaxPlus 384, Molecular Devices, CA, USA). Briefly, SOD activity was measured with Ransod Kit (Randox Laboratories Limited, Crumlin, UK) as described earlier (Barros et al., 2019), based on the ability of this enzyme to inhibit superoxide radical dependent reactions. CAT activity was determined based on the dismutation of $\mathrm{H}_{2} \mathrm{O}_{2}\left(240 \mathrm{~nm}, \varepsilon=0.04 \mathrm{mM}^{-1} \mathrm{~cm}^{-1}\right)$ as described in Barros et al. (2019). GPx activity was determined according to Flohé and Günzler (1984), and Barros et al. (2019) based on the oxidation of reduced nicotinamide adenine dinucleotide phosphate ( $340 \mathrm{~nm}, \varepsilon=6.2 \mathrm{mM}^{-1} \mathrm{~cm}^{-1}$ ). GST activity was determined according to Habig et al. (1974), and Barros et al. (2019), based on the conjugation reaction of GSH and 1chloro-2,4-dinitrobenzene ( $340 \mathrm{~nm}, \varepsilon=9.6 \mathrm{mM}^{-1} \mathrm{~cm}^{-1}$ ).

\subsection{Statistical analyses}

The $\mathrm{EC}_{20}$ of $\mathrm{Ag}^{+}$or AgNPs was calculated using PriProbit 1.63. One-way ANOVAs were used to test the effects of $\mathrm{Ag}$ forms on the activities of antioxidant enzymes or alterations in protein content. Tukey's multiple comparisons were used to identify where significant differences occurred. Analyses were performed in Prism 7.0 (GraphPad software Inc., CA, USA).

Heatmaps and cluster analyses of quantified proteins were performed with GProX v 1.1.15 (Rigbolt et al., 2011). The proteins from heatmaps were clustered by their behavioural profiles using unsupervised clustering fuzzy c-means algorithm implemented in the Mfuzz package (Kumar and Futschik, 2007). An upper and lower ratio $\operatorname{limit}$ of $\log 2(2)$ and $\log 2(0.5)$ was used for inclusion into the clusters. The most representative biological processes associated with each cluster were featured based on UniProt Gene Ontology database, followed by enrichment analysis within GProX, using a binomial statistical test with Benjamini-Hochberg adjustment $(P<0.05)$. This analysis required a comparison of other clusters with the cluster representing a group of proteins, the amount of which decreased under exposure to $\mathrm{Ag}^{+}$and AgNPs (cluster 5 in At72 and cluster 4 in At61).

Principal Component Analysis (PCA) was used to associate the responses of antioxidant enzymes with the protein content in fungi exposed to $\mathrm{Ag}^{+}$or AgNPs. Analysis was done with PAST 3.14 (Hammer et al., 2001).

\section{Results}

\subsection{Characterization of AgNPs}

In the presence of At72, stability of AgNPs increased ( $\zeta$ at T0: $-25.3 \pm 0.3$, T1: $-30.4 \pm 1.6$; polydispersity index at T0: $0.46 \pm 0.21, \mathrm{~T} 1: 0.44 \pm 0.07)$ and HDDs remained small along the 
exposure period (T0: $295.8 \pm 43 \mathrm{~nm}$ and $37.8 \pm 4 \mathrm{~nm}$; $\mathrm{T} 1: 292.9 \pm$ $51 \mathrm{~nm}$ and $42.9 \pm 7 \mathrm{~nm}$ ), while an opposite trend was observed in the presence of At61 (Table 1).

In the presence of either ecotype, the concentration of dissolved $\mathrm{Ag}^{+}$from AgNPs in the medium was below the limit of quantification $\left(<0.2 \mu \mathrm{g} \mathrm{L}{ }^{-1}\right)$ at $\mathrm{T} 0$ and $\mathrm{T} 1$. At $\mathrm{EC}_{20}$, the bioaccumulation of $\mathrm{Ag}$ from AgNPs was $>40$ times higher in At61 than in At72 (At61 vs At72: $107.4 \pm 18.7$ vs $2.6 \pm 0.9 \mu \mathrm{g} \mathrm{g}^{-1}$ dry mass). At61 and At72 adsorbed $3.87 \pm 2.6$ and $0.62 \pm 0.3 \mu \mathrm{g}$ of $\mathrm{Ag}^{+} \mathrm{g}^{-1}$ dry mass, respectively, corresponding to $1.6 \pm 1.1 \%$ and $5.7 \pm 3.2 \%$ of the total $\mathrm{Ag}$ added as AgNPs per experimental unit, respectively.

\subsection{Effects of AgNPs and $\mathrm{Ag}^{+}$on fungal growth}

The exposure of both $A$. tetracladia ecotypes to AgNPs or $\mathrm{Ag}^{+}$ resulted in a dose-dependent reduction in their specific growth rates (Fig. S1). The $\mathrm{EC}_{20}$ of AgNPs for At61 and At72 were 158.9 $(81.7-246.5) \mu \mathrm{g} \mathrm{L}^{-1}$ and $7.5(0.1-39.4) \mu \mathrm{g} \mathrm{L}^{-1}$, respectively, whereas the $\mathrm{EC}_{20}$ of $\mathrm{Ag}^{+}$for these two ecotypes were 117.4 (97.7-135.8) $\mu \mathrm{g} \mathrm{L}^{-1}$ and $18.7(0.5-41.0) \mu \mathrm{g} \mathrm{L}^{-1}$, respectively.

\subsection{Effects of AgNPs and $\mathrm{Ag}^{+}$on fungal proteomes}

A total of 358 and 516 proteins were quantified by SWATH-MS in At72 and At61, respectively, after exposure to $\mathrm{EC}_{20}$ of either $\mathrm{Ag}$ form (Tables S2 and S3). However, only 172 proteins of At72 and 260 proteins of At61 showed significant alteration (one-way ANOVA, $P<0.05$ ) upon exposure to either form of silver (Tables S2 and S3). Out of these, 71 proteins were common to both ecotypes (Fig. 1A). Among the proteins altered in At72, 51.7\% and $58.1 \%$ increased their content after $\mathrm{Ag}^{+}$and $\mathrm{AgNP}$ exposure, respectively; while in At61, those percentages were relatively higher (77.7\% and 76.5\%, respectively; Fig. 1B). Heatmap analyses of the dynamic profiles of altered protein content (Figs. $2 \mathrm{~A}$ and $3 \mathrm{~A}$ ) allowed the generation of 7 clusters for At72 and 6 clusters for At61, according to their behavioural profile (Figs. 2B and 3B).

Due to the lack of a database for $A$. tetracladia, related species were considered for the identification and functional characterization of proteins. In At72, the content of all the 16 proteins in cluster 1 increased, while all the 24 proteins in cluster 5 decreased considerably by either Ag form (Table S2; Fig. 2B). Cluster 2 included 38 proteins, the content of all increased strongly by $\mathrm{Ag}^{+} ; \mathrm{AgNPs}$ led to a moderate increase in the level of 31 proteins, but a slight decrease of the remaining. In cluster 3 (22 proteins), $\mathrm{Ag}^{+}$considerably decreased the content of all proteins, while AgNPs led to a moderate decrease in 20 proteins. The content of all proteins in cluster 4 (19 proteins), decreased by AgNPs and increased by $\mathrm{Ag}^{+}$, except methylthioribose-1-phosphate isomerase. In cluster 6 (28 proteins), AgNPs increased considerably the content of all proteins, while only few were increased by $\mathrm{Ag}^{+}$. In cluster 7, the content of all 29 proteins increased moderately by AgNPs, but decreased by $\mathrm{Ag}^{+}$. In the case of At61, the content of all 75 proteins from cluster 1 increased by AgNPs, while $\mathrm{Ag}^{+}$increased the content of 68 pro- teins (Table S3; Fig. 3B). In cluster $2 \mathrm{Ag}^{+}$increased moderately the content of all 11 proteins, whereas AgNPs decreased the content of all except RecA. Both Ag forms strongly increased the protein content in cluster 3 (33 proteins) and cluster 5 (90 proteins), but strongly decreased those in cluster 4 ( 25 proteins). In cluster 6 (26 proteins), the content of all proteins of At61 decreased strongly by AgNPs and moderately by $\mathrm{Ag}^{+}$.

\subsection{Oxidative stress biomarkers and their relationship with proteomics}

Exposure to either Ag form at $\mathrm{EC}_{20}$ or to AgNPs, at a concentration corresponding to $\mathrm{EC}_{20}$ of $\mathrm{Ag}^{+}$, induced antioxidant enzyme activities in both fungal ecotypes (one-way ANOVA, $P<0.05$ ) (Fig. S3, Table S1). In At72, AgNPs led to a higher stimulation of the activity of CAT (261.5\%) followed by SOD, GST and GPx (Fig. S3A); whereas the exposure to $\mathrm{Ag}^{+}$led to a higher increase in the activities of GST (384.0\%) and CAT (379\%), followed by SOD and GPX (Fig. S3A). In At61, the increase in activity of CAT was higher at $\mathrm{EC}_{20}$ for either form of $\mathrm{Ag}\left(\mathrm{Ag}^{+}: 257.1 \%, \mathrm{AgNPs}\right.$ : 239.9\%) than activities of SOD, GST and GPx (Fig. S3B). In At72, at the concentration of AgNPs corresponding to $\mathrm{EC}_{20}$ of $\mathrm{Ag}^{+}$ (117.4 $\left.\mu \mathrm{g} \mathrm{L}^{-1}\right)$, the activity of CAT was the highest $(415 \%)$ (Fig. S3C), and activities of the other enzymes were similar to or lower than that observed at same exposure concentration of $\mathrm{Ag}^{+}$ (Fig. S3A). In At61, the enzyme activities were considerably lower at the concentration of AgNPs corresponding to $\mathrm{EC}_{20}$ of $\mathrm{Ag}^{+}$ (18.7 $\mu \mathrm{g} \mathrm{L}^{-1}$, Fig. S3D) than that observed at the same concentration of $\mathrm{Ag}^{+}$(Fig. S3B).

The PCA of overall responses of antioxidant enzymes and proteins involved in antioxidant activities in A. tetracladia exposed to $\mathrm{Ag}^{+}$and AgNPs (Fig. 4) showed that the PC1 explained $77.5 \%$ and 73.9\% of the total variance for At72 (Fig. 4A) and At61 (Fig. 4B), respectively. In At72, controls and treatments with $\mathrm{Ag}^{+}$and AgNPs were separated along the PC1 based on the responses of antioxidant biomarkers and related proteins (Fig. 4A). For At61, the segregation between $\mathrm{Ag}^{+}$and $\mathrm{AgNPs}$ treatments was less pronounced (Fig. 4B). In At72, all antioxidant enzymatic biomarkers and the related proteins were positively associated with $\mathrm{Ag}^{+}$(Fig. $4 \mathrm{~A}$ ). In At61, the activities of the antioxidant enzymes were positively associated with $\mathrm{Ag}^{+}$, whereas the content of the proteins involved in antioxidant activities were mostly associated with AgNPs (Fig. 4B).

\section{Discussion}

Our findings suggest that the toxicity of AgNPs can mainly be attributed to the nanoparticle itself, as supported by the negligible amount of dissolved $\mathrm{Ag}^{+}$released from AgNPs in the presence of both aquatic fungal ecotypes. As hypothesised, the ecotype from polluted stream was more tolerant to AgNPs than the ecotype from non-polluted stream. However, an opposite trend was observed for the effects of $\mathrm{Ag}^{+}$. The absence of silver in the metal-polluted

Table 1

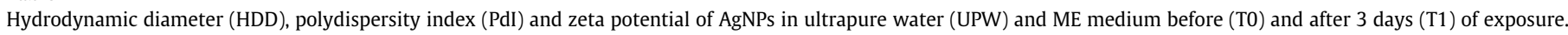
Mean $\pm \mathrm{SD}, \mathrm{n}=3$.

\begin{tabular}{|c|c|c|c|c|c|c|}
\hline \multirow[t]{2}{*}{ Sample } & \multirow[t]{2}{*}{ Zeta potential (mV) } & \multirow[t]{2}{*}{ PdI } & \multicolumn{2}{|l|}{ Peak 1} & \multicolumn{2}{|l|}{ Peak 2} \\
\hline & & & Average HDD (nm) & Area Intensity (\%) & Average HDD (nm) & Area Intensity (\%) \\
\hline UPWT0 & $-40.7 \pm 0.5$ & $0.29 \pm 0.00$ & $31.9 \pm 0.1$ & $100 \pm 0$ & - & - \\
\hline UPWT1 & $-40.6 \pm 0.5$ & $0.29 \pm 0.00$ & $32.1 \pm 0.1$ & $100 \pm 0$ & - & - \\
\hline $\mathrm{ME}+$ At61T0 & $-27.7 \pm 0.8$ & $0.53 \pm 0.09$ & $295.9 \pm 48$ & $83.6 \pm 4$ & $41.7 \pm 11$ & $16.4 \pm 4$ \\
\hline $\mathrm{ME}+$ At61T1 & $-19.3 \pm 2$ & $0.50 \pm 0.14$ & $377.7 \pm 187$ & $88.9 \pm 7$ & $40.3 \pm 27$ & $11.1 \pm 7$ \\
\hline $\mathrm{ME}+$ At72T0 & $-25.3 \pm 0.3$ & $0.46 \pm 0.21$ & $295.8 \pm 43$ & $76.9 \pm 2$ & $37.8 \pm 4$ & $23.1 \pm 2$ \\
\hline $\mathrm{ME}+$ At72T1 & $-30.4 \pm 1.6$ & $0.44 \pm 0.07$ & $292.9 \pm 51$ & $68.1 \pm 1$ & $42.9 \pm 7$ & $31.9 \pm 1$ \\
\hline
\end{tabular}




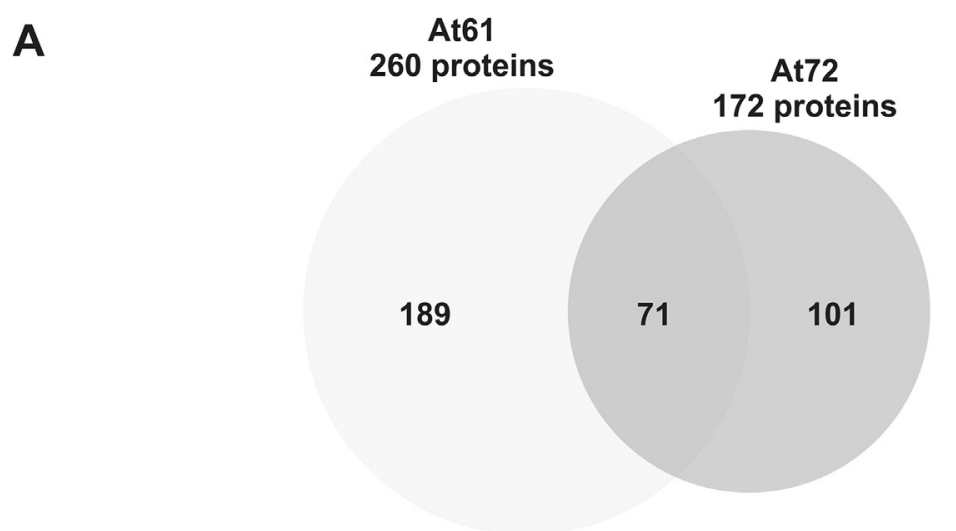

Total: 361 proteins

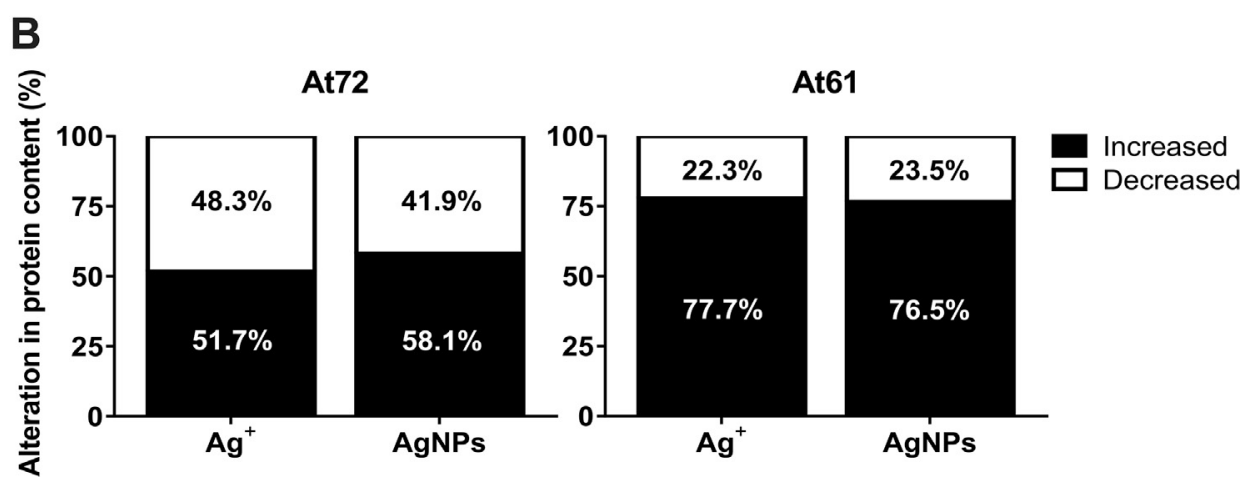

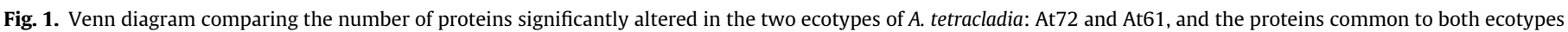
(A). Percentage of significantly altered proteins, the content of which increased (in black) or decreased (in white) under exposure to $\mathrm{Ag}^{+}$or AgNPs (B).

stream, from which At61 was isolated, may also contribute to explain the low tolerance of this ecotype to $\mathrm{Ag}^{+}$. Moreover, fungi are sensitive to inorganic nutrients (e.g. $\mathrm{NO}_{3}^{-}$; Fernandes et al., 2014), which may alter the toxicity of metals (Fernandes et al., 2009). The exposure to the lowest tested concentration of nitrate led to an increase in fungal biomass of At72 (ca. 15\%, $P<0.05$; Fig. S2), but not of At61. This suggests that the nitrate from $\mathrm{AgNO}_{3}$ alleviated the toxicity of $\mathrm{Ag}^{+}$to At72.

The aggregation state of nanoparticles plays a critical role in toxicity, as dispersed AgNPs exhibit greater negative effects over aggregated ones (Dorjnamjin et al., 2008). Indeed, DLS and zeta potential supported these findings in our study; higher agglomeration and lesser stability of nanoparticles probably explained the lower impacts of AgNPs in At61 (Table 1). Moreover, the bioaccumulation percentage of $\mathrm{Ag}$ by At61 was almost twice than by At72, reflecting the higher tolerance of the former to AgNPs.

Gene Ontology enrichment analysis based on protein clustering predicted that different biological processes are likely to be associated with the responses of $A$. tetracladia ecotypes to $\mathrm{Ag}^{+}$or AgNPs (Figs. 2C and $3 \mathrm{C}$ ). Some of the predicted processes were common to both stressors in both fungal ecotypes, such as processes related to protein homeostasis. Particularly, in At72, the content of proteins involved in transcription (positive regulation of RNA polymerase II transcriptional preinitiation complex assembly) and peptide catabolism increased under exposure to $\mathrm{Ag}^{+}$more than to AgNPs (clusters 4; Fig. 2C); the content of proteins involved in $\alpha$ amino acid biosynthesis and signal recognition particle (SRP)-dependent protein translocation increased moderately by $\mathrm{Ag}^{+}$, but decreased by AgNPs (clusters 2; Fig. 2C). This indicates that protein homeostasis was strongly affected by AgNPs in At72. In At61, protein homeostasis was dependent on transcription (DNA-templated regulation and termination), ribosomal subunit assembly and biogen- esis, SRP-dependent protein translocation, $\boldsymbol{\alpha}$-amino acid biosynthesis and transport, and protein refolding and transport, as the related proteins were up-regulated mainly by AgNPs (clusters 1, 3 and 5; Fig. 3C). Moreover, 23.9\% of the common proteins in both ecotypes were predicted to be involved in protein biosynthesis (translation). In At72, both Ag forms led to up-regulation of proteins associated with translation (all except cluster 4; Fig. 2C), particularly under exposure to AgNPs. A similar trend was found in At61: the translation-related proteins (cluster 1, 3 and 5; Fig. 3C) were up-regulated particularly by AgNPs. Our findings agree with the studies showing effects of AgNPs on protein biosynthesis, transcription and translation in microbes (Yuan et al., 2013; Mirzajani et al., 2014). Another highly overrepresented process in both ecotypes (cluster 1 in At72; cluster 3 in At61) was related to cell cycle (Figs. 2C and 3C), as the involved proteins (e.g. fimbrin) increased by both $\mathrm{Ag}$ forms, consistently to that found in other biological systems (Nair and Chung, 2014; Kang et al., 2016).

Protein degradation is crucial for cell protection under stress (Zhu et al., 2006). A highly overrepresentation of the ubiquitindependent endoplasmic reticulum-associated protein degradation (ERAD) was observed in At72 in response to $\mathrm{Ag}^{+}$(cluster 1, 2 and 4; Fig. 2C) but not to AgNPs. Consistently, the protein level expressed by $C D C 48$ gene increased in At72, particularly under exposure to $\mathrm{Ag}^{+}$. The $C D C 48$ gene is essential to ERAD pathways, and its mutation is linked to apoptosis in yeast (Braun et al., 2006). Apoptosis allows a rapid removal of unwanted or damaged cells affording nutrients and space for the fittest ones (Azevedo et al., 2009).

Vesicle-mediated transport is involved in exporting macromolecules across cell wall in fungi and concentration of these fungal substances in vesicles can increase their food acquisition efficiency (Casadevall et al., 2009). In At72, the impairment of 
A

$\mathrm{N}=172$ proteins

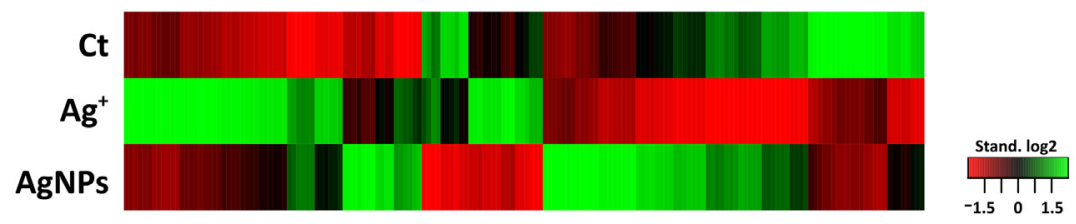

B

Cluster 1

Cluster 2

Cluster 3
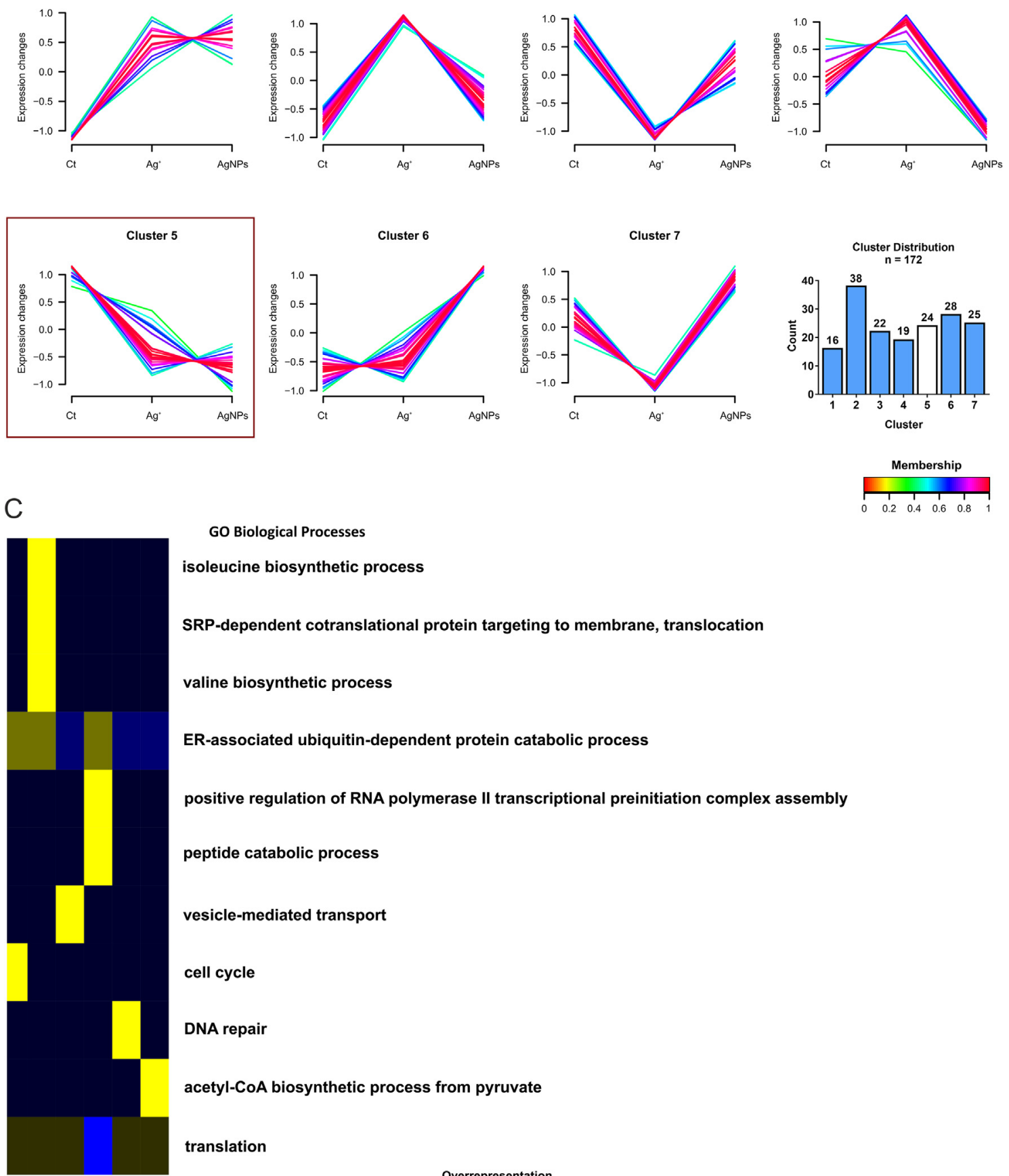

GO Biological Processes

isoleucine biosynthetic process

SRP-dependent cotranslational protein targeting to membrane, translocation

valine biosynthetic process

ER-associated ubiquitin-dependent protein catabolic process

positive regulation of RNA polymerase II transcriptional preinitiation complex assembly

peptide catabolic process

vesicle-mediated transport

cell cycle

DNA repair

acetyl-CoA biosynthetic process from pyruvate

translation

$\begin{array}{llllll}1 & 2 & 3 & 4 & 6 & 7\end{array}$

Overrepresentation
None High

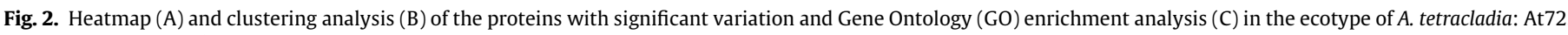

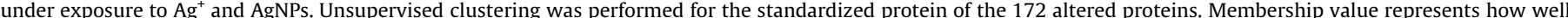

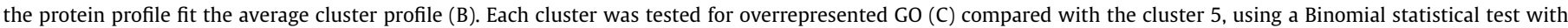
Benjamini-Hochberg adjustment $(P<0.05)$. Ct: Control. 
A

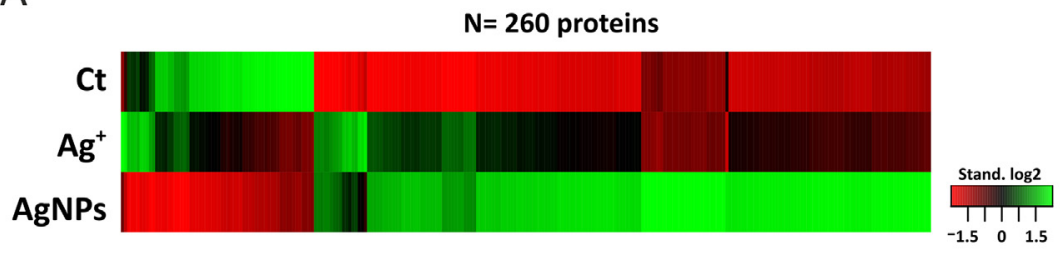

B
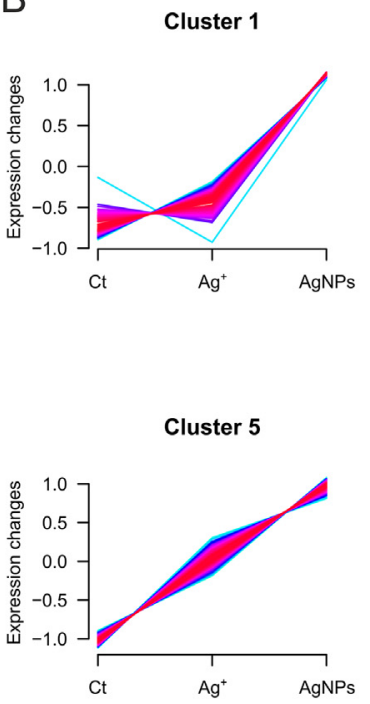

Cluster 2

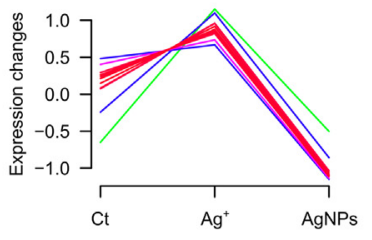

Cluster 6

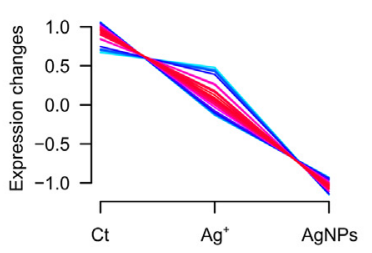

Cluster 3
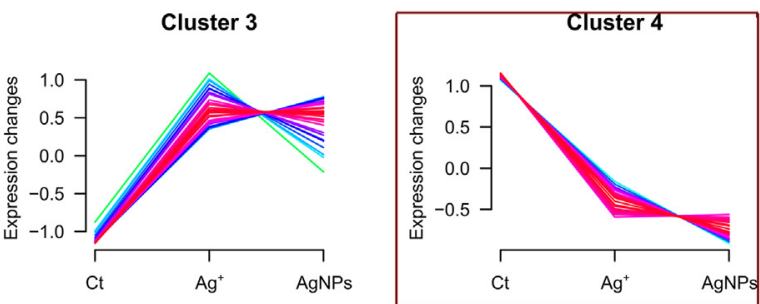

C

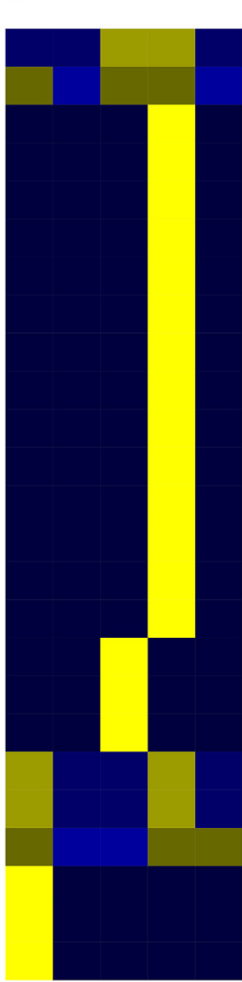

1235

GO Biological Processes

protein transport

translation

cytoplasmic translation

ribosomal small subunit assembly

glyoxylate cycle

GTP biosynthetic process

UTP biosynthetic process

CTP biosynthetic process

fatty acid biosynthetic process

amino acid transport

isoleucine biosynthetic process

valine biosynthetic process

ascospore formation

protein refolding

cell redox homeostasis

glycerol-3-phosphate catabolic process

cell cycle

SRP-dependent cotranslational protein targeting to membrane, translocation

cell division

regulation of transcription, DNA-templated

carbohydrate metabolic process

tricarboxylic acid cycle

ATP synthesis coupled proton transport

DNA-templated transcription, termination

ribosome biogenesis

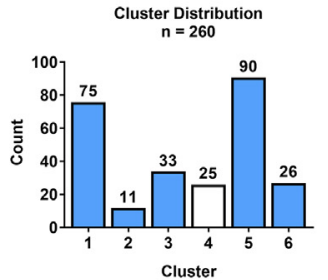

Membership

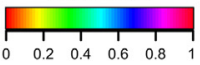

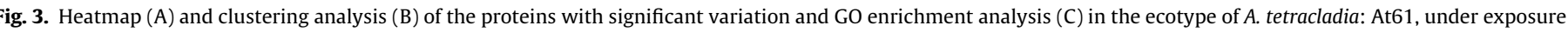

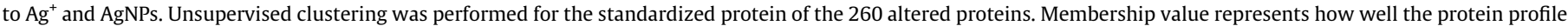

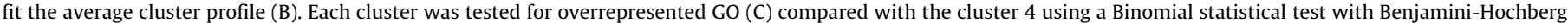
adjustment $(P<0.05)$. Ct: Control. 
A

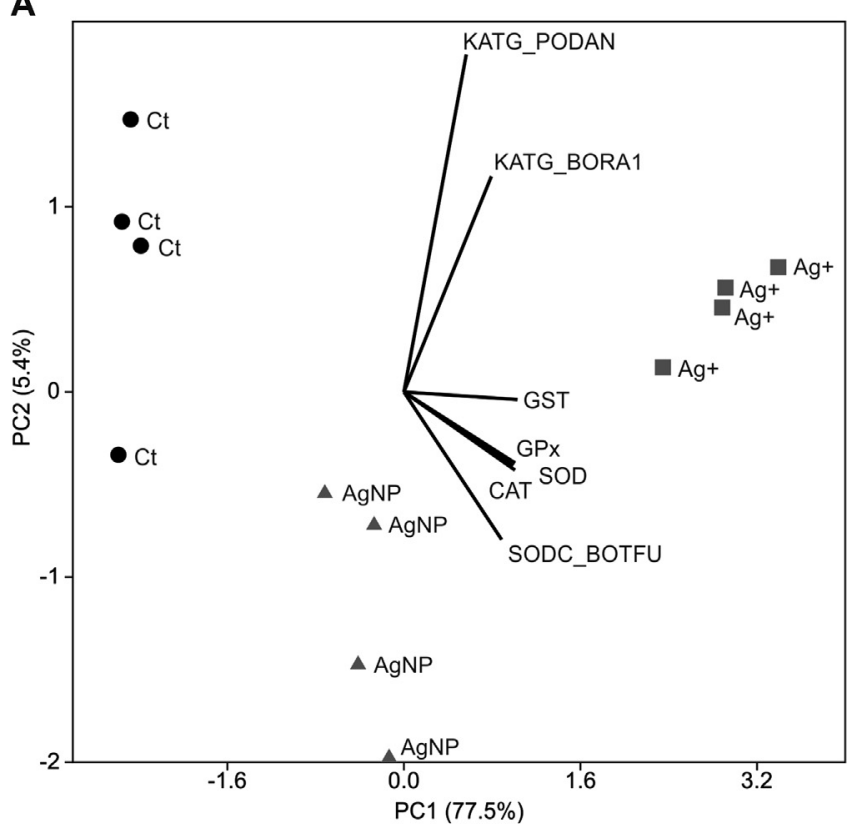

B

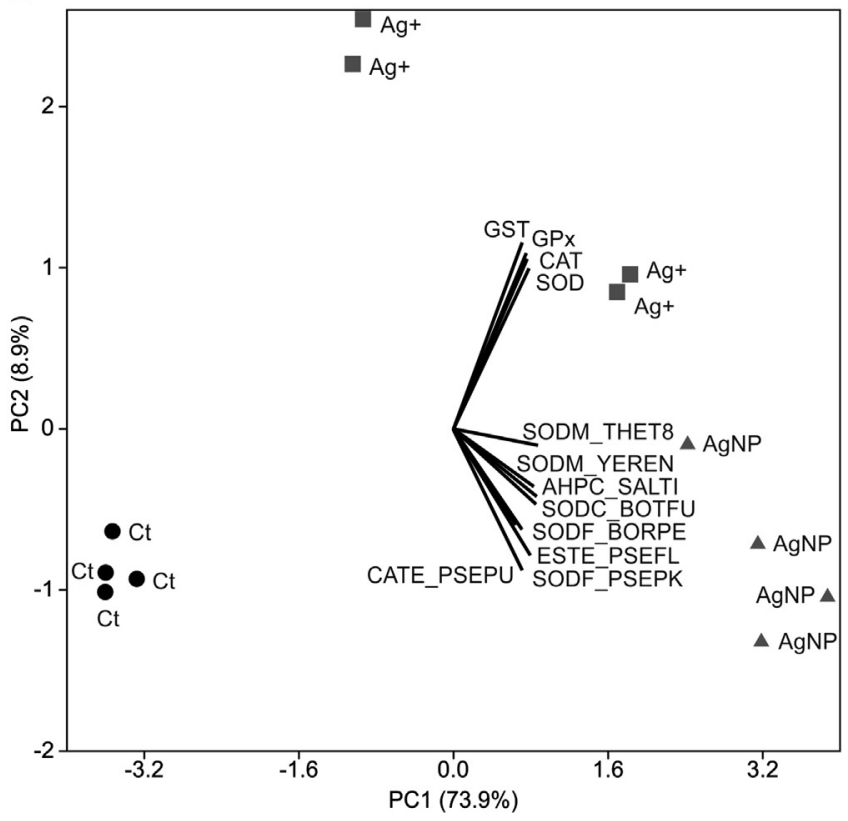

Fig. 4. Principal component analysis of overall responses of proteins involved in antioxidant activities and activities of antioxidant enzymes in two ecotypes of $A$. tetracladia: At72 (A), and At61 (B), unexposed (Ct) or exposed for 3 days to $\mathrm{EC}_{20}$ of AgNPs or $\mathrm{Ag}^{+}$. KATG_PODAN: catalase-peroxidase (Podospora anserina); KAT_BORA1: catalase-peroxidase (Bordetella avium); CATE_PSEPU: catalase HPII (Pseudomonas putida); AHPC_SALTI: alkyl hydroperoxide reductase C (Salmonella typhi); ESTE_PSEFL: arylesterase (Pseudomonas fluorescens); SODC_BOTFU: superoxide dismutase [Cu-Zn] (Botryotinia fuckeliana); SODF_BORPE: superoxide dismutase [Fe] (Bordetella pertussis); SODF_PSEPK: superoxide dismutase [Fe] (Pseudomonas putida); SODM_THET8: superoxide dismutase [Mn] (Thermus thermophilus) and SODM_YEREN: superoxide dismutase [Mn] (Yersinia enterocolitica).

vesicle-mediated transport is suggested by down-regulation of related proteins (cluster 3; Fig. 2C), mainly under exposure to $\mathrm{Ag}^{+}$. AgNPs can increase cell membrane permeability by progressive release of lipopolysaccharides and membrane proteins, leading to cell death (Sondi and Salopek-Sondi, 2004). In At61, the overrepresentation of fatty acids biosynthesis (cluster 5,
Table S3) might be recognized as a mechanism for recovery of damaged membrane lipids (e.g. ergosterol) mainly under exposure to AgNPs.

Several metabolic processes involved in energy production were also highlighted by the GO enrichment analysis although differently in each fungal ecotype. In At72, proteins involved in the synthesis of acetyl-CoA from pyruvate (cluster 7, Fig. 2C) increased under exposure to AgNPs but decreased under $\mathrm{Ag}^{+}$exposure. For At61 (Fig. 3C), the featured processes were ATP synthesis coupled with proton transport (cluster 1), carbohydrate metabolism (clusters 1 and 5), tricarboxylic acid cycle (clusters 1, 5 and 6) and glyoxylate cycle (cluster 5 ). The majority of proteins involved in these metabolic processes increased mainly by AgNPs, suggesting increased need of energy in fungal cells to compensate the stress induced by nanoparticles and contributing to explain the higher tolerance to this silver form in At61.

Sporulation of freshwater fungi is a sensitive endpoint to both Ag forms (Pradhan et al., 2011), potentially compromising the dispersal and survival of fungi in streams. However, some studies reported an increase in fungal reproduction under low doses of AgNPs (Kasprowicz et al., 2010; Tlili et al., 2016). In our study, the overrepresentation of ascospore formation and up-regulation of the proteins involved in cell division (Fig. 3C) can be envisaged as a survival strategy of At61 under the stress induced by both $\mathrm{Ag}$ forms considering that: i) fungal spores have thick cell-walls, energy reserves and low metabolic rates (Moore-Landecker, 2002) and ii) the production of asexual spores often decrease under stress conditions (Pradhan et al., 2011).

The process of cellular redox homeostasis was also featured by GO enrichment analysis in At61 (cluster 5; Fig. 3C). This is crucial for the preservation of several cellular processes including responses to ROS, signalling and removal of xenobiotics (Ayer et al., 2014). The up-regulation of alkyl hydroperoxide reductase in At61 by either form of $\mathrm{Ag}$ supports its role as the first line of defense against peroxides (Ayer et al., 2014). The up-regulation of proteins with antioxidant activities (e.g. SOD) upon exposure to AgNPs supports the higher tolerance of At61 to this toxicant. A similar trend was observed for arylesterase, which reduces the oxidative stress by hydrolysing lipid peroxidases in oxidized lipoproteins (Aslan et al., 2008). In At61, the up-regulation of glycerol-3-phosphate (G3P) catabolism related proteins (e.g. G3P dehydrogenase) was mainly observed under AgNPs. Besides being involved in carbohydrate and lipid biosyntheses, G3P dehydrogenase play a crucial role in stress responses as observed in algae (Lai et al., 2015). At61 also exhibited increased level of glutathione synthetase under exposure to $\mathrm{Ag}^{+}$or AgNPs, supporting the role of glutathione in maintaining cellular redox homeostasis (Ayer et al., 2014). In At61, both Ag forms stimulated the SOD activity, pinpointing the efficiency of this enzyme to counteract the superoxide anions (Lubrano and Balzan, 2015). These outcomes suggest higher efficiency of At61 to combat the oxidative stress induced by AgNPs as further supported by the correlation between responses of antioxidant enzymes and related proteins (Fig. 4). In At61, the biosynthesis of nucleosides triphosphate (NTPs) was also overrepresented (cluster 5; Fig. 3C); NTPs are the building blocks of DNA and RNA, and supply energy to several cellular reactions. In At61, proteins related to the biosynthesis of NTPs, including the nucleoside diphosphate kinase, increased mainly under exposure to AgNPs. In At72, DNA repair was among the most overrepresented process (cluster 6). Indeed, RuvB-like helicase 1 and Casein kinase I homolog hhp2 are key proteins involved in DNA damage response (Dhillon and Hoekstra, 1994; Peterson and Côté, 2004); both proteins increased considerably by AgNPs, indicating DNA damage in At72. This can further support the lower tolerance of At72 to AgNPs than At61. 


\section{Conclusions}

Our study showed higher tolerance of the fungal ecotype from metal-polluted stream (At61) to AgNPs than the ecotype from non-polluted stream (At72). The negligible amount of extracellular dissolution of ions, released from nanoparticulate $\mathrm{Ag}$, suggests a minor role of the dissolved $\mathrm{Ag}^{+}$in the toxicity of AgNPs to both fungal ecotypes. Our results also reinforced the role of antioxidant enzymes of the ascorbate-glutathione cycle against the oxidative stress induced by both $\mathrm{Ag}$ forms. The proteomic responses suggest that the majority of proteins controlling biological pathways differed with the $\mathrm{Ag}$ form and fungal ecotype. Several of these proteins might be used as potential biomarkers for the stress induced by AgNPs and/or $\mathrm{Ag}^{+}$. The responses in At72 were mostly associated with DNA repair, peptide and protein catabolism, cell cycle and vesicle-mediated transport; whereas cellular redox homeostasis, cell cycle, cell division, protein homeostasis, translation, protein transport and refolding, energy production, spore formation and nucleic acids biosynthesis were mainly associated with At61. Our study provides evidence that the mechanisms of action and the environmental background of microorganisms are key factors to determine biological responses to toxicants. This is particularly relevant in face of the increasing release of emergent contaminants into natural environments.

\section{Author contributions}

DB and AP conducted the experimental and analytical parts for this work. The experimental and manuscript designs result from discussions between AP, DB, CP and FC. All authors contributed to the manuscript writing and provided intellectual input to the manuscript.

\section{Declaration of Competing Interest}

The authors declare that they have no known competing financial interests or personal relationships that could have appeared to influence the work reported in this paper

\section{Acknowledgement}

This work was supported by the strategic programme UID/ BIA/04050/2019 and the Emergemix project (PTDC/BIABMA/30922/2017) funded by national funds through the Portuguese Foundation for Science and Technology (FCT) I.P. and by the ERDF through the COMPETE2020 - Programa Operacional Competitividade e Internacionalização. FCT also supported D. Barros (SFRH/BD/80407/2011).

\section{Appendix A. Supplementary data}

Supplementary data to this article can be found online at https://doi.org/10.1016/j.scitotenv.2019.135385.

\section{References}

Akter, M., Sikder, M.T., Rahman, M.M., Ullah, A.K.M.A., Hossain, K.F.B., Banik, S., Hosokawa, T., Saito, T., Kurasaki, M., 2017. A systematic review on silver nanoparticles-induced cytotoxicity: physicochemical properties and perspectives. J. Adv. Res. 9, 1-16. https://doi.org/10.1016/j.jare.2017.10.008.

Anjo, S.I., Santa, C., Manadas, B., 2014. Short GeLC-SWATH: a fast and reliable quantitative approach for proteomic screenings. Proteomics 15 (4), 757-762. https://doi.org/10.1002/pmic.201400221.

Aslan, M., Nazligul, Y., Horoz, M., Bolukbas, C., Bolukbas, F.F., Gur, M., Celik, H., Erel, O., 2008. Serum paraoxonase-1 activity in Helicobacter pylori infected subjects.

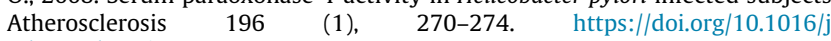
atherosclerosis.2006.10.024.
Ayer, A., Gourlay, C.W., Dawes, I.W., 2014. Cellular redox homeostasis, reactive oxygen species and replicative ageing in Saccharomyces cerevisiae. FEMS Yeast Res. 14 (1), 60-72. https://doi.org/10.1111/1567-1364.12114.

Azevedo, M.M., Almeida, B., Ludovico, P., Cássio, F., 2009. Metal stress induces programmed cell death in aquatic fungi. Aquat. Toxicol. 92 (4), 264-270. https://doi.org/10.1016/j.aquatox.2009.02.010.

Bai, X., Liu, F., Liu, Y., Li, C., Wang, S., Zhou, H., Wang, W., Zhu, H., Winkler, D.A., Yan, B., 2017. Toward a systematic exploration of nano-bio interactions. Toxicol. Appl. Pharmacol. 323, 66-73. https://doi.org/10.1016/j.taap.2017.03.011.

Barros, D., Pradhan, A., Mendes, V.M., Manadas, B., Santos, P.M., Pascoal, C., Cássio, F., 2019. Proteomics and antioxidant enzymes reveal different mechanisms of toxicity induced by ionic and nanoparticulate silver in bacteria. Environ. Sci.Nano 6 (4), 1207-1218. https://doi.org/10.1039/c8en01067f.

Behra, R., Sigg, L., Clift, M.J., Herzog, F., Minghetti, M., Johnston, B., Petri-Fink, A., Rothen-Rutishauser, B., 2013. Bioavailability of silver nanoparticles and ions: from a chemical and biochemical perspective. J. R. Soc. Interface 10 (87), 20130396. https://doi.org/10.1098/rsif.2013.0396.

Blaser, S.A., Scheringer, M., MacLeod, M., Hungerbühler, K., 2008. Estimation of cumulative aquatic exposure and risk due to silver: contribution of nanofunctionalized plastics and textiles. Sci. Total Environ. 390 (2-3), 396-409. https://doi.org/10.1016/j.scitotenv.2007.10.010.

Braun, R.J., Zischka, H., Madeo, F., Eisenberg, T., Wissing, S., Buttner, S., Engelhardt, S. M., Buringer, D., Ueffing, M., 2006. Crucial mitochondrial impairment upon CDC48 mutation in apoptotic yeast. J. Biol. Chem. 281 (35), 25757-25767. https://doi.org/10.1074/jbc.M513699200.

Burdușel, A.-C. Gherasim, O., Grumezescu, A.M., Mogoantă, L., Ficai, A., Andronescu, E., 2018. Biomedical applications of silver nanoparticles: an up-to-date overview. Nanomaterials (Basel) 8 (9), pii: E681.

Casadevall, A., Nosanchuk, J.D., Williamson, P., Rodrigues, M.L., 2009. Vesicular transport across the fungal cell wall. Trends Microbiol. 17 (4), 158-162. https:// doi.org/10.1016/j.tim.2008.12.005.

Dhillon, N., Hoekstra, M.F., 1994. Characterization of two protein kinases from Schizosaccharomyces pombe involved in the regulation of DNA repair. EMBO J. 13 (12), 2777-2788.

Dorjnamjin, D., Ariunaa, M., Shim, Y.K., 2008. Synthesis of silver nanoparticles using hydroxyl functionalized ionic liquids and their antimicrobial activity. Int. J. Mol. Sci. 9 (5), 807-819. https://doi.org/10.3390/ijms9050807.

European Commission, 2012. Types and Uses of Nanomaterials, Including Safety Aspects. Commission Staff Working Paper. Accompanying the Communication from the Commission to the European Parliament. The Council and the European Economic and Social Committee on the Second Regulatory Review on Nanomaterials.

Fernandes, I., Duarte, S., Pascoal, C., Cássio, F., 2009. Mixtures of zinc and phosphate affect leaf litter decomposition by aquatic fungi in streams. Sci. Total Environ. 407 (14), 4283-4288.

Fernandes, I., Seena, S., Pascoal, C., Cássio, F., 2014. Elevated temperature may intensify the positive effects of nutrients on microbial decomposition in streams. Freshwater Biol. 59 (11), 2390-2399. https://doi.org/10.1111/ fwb. 12445 .

Flohé, L., Günzler, W.A., 1984. Assays of glutathione peroxidase. Method Enzymol. 105, 114-121.

Gottschalk, F., Kost, E., Nowack, B., 2013. Engineered nanomaterials in water and soils: a risk quantification based on probabilistic exposure and effect modeling. Environ. Toxicol. Chem. 32 (6), 1278-1287. https://doi.org/10.1002/etc.2177.

Habig, W.H., Pabst, M.J., Jakoby, W.B., 1974. Glutathione S-transferases - first enzymatic step in mercapturic acid formation. J. Biol. Chem. 249 (22), 7130 7139.

Hammer, Ø., Harper, D.A.T., Ryan, P.D., 2001. PAST: paleontological statistics software package for education and data analysis. Palaeontol. Electron. 4 (1), 9 pp.

He, D., Dorantes-Aranda, J.J., Waite, T.D., 2012. Silver nanoparticle-algae interactions: oxidative dissolution, reactive oxygen species generation and synergistic toxic effects. Environ. Sci. Technol. 46, 8731-8738. https://doi.org/ 10.1021/es300588a.

Kaegi, R., Sinnet, B., Zuleeg, S., Hagendorfer, H., Mueller, E., Vonbank, R., Boller, M., Burkhardt, M., 2010. Release of silver nanoparticles from outdoor facades. Environ. Pollut. 158 (9), 2900-2905. https://doi.org/10.1016/j. envpol.2010.06.009.

Kang, J.S., Bong, J., Choi, J.-S., Henry, T.B., Park, J.-W., 2016. Differentially transcriptional regulation on cell cycle pathway by silver nanoparticles from ionic silver in larval zebrafish (Danio rerio). Biochem. Biophys. Res. 479 (4), 753758. https://doi.org/10.1016/j.bbrc.2016.09.139.

Kasprowicz, M.J., Kozioł, M., Gorczyca, A., 2010. The effect of silver nanoparticles on phytopathogenic spores of Fusarium culmorum. Can. J. Microbiol. 56 (3), 247253. https://doi.org/10.1139/w10-012.

Kumar, L., Futschik, M.E., 2007. Mfuzz: a software package for soft clustering of microarray data. Bioinformation 2 (1), 5-7. https://doi.org/10.6026/ 97320630002005.

Lai, X.J., Yang, R., Luo, Q.J., Chen, J.J., Chen, H.M., Yan, X.J., 2015. Glycerol-3phosphate metabolism plays a role in stress response in red alga Pyropia haitanensis. J. Phycol. 51 (2), 321-331. https://doi.org/10.1111/jpy.12276.

Lubrano, V., Balzan, S., 2015. Enzymatic antioxidant system in vascular inflammation and coronary artery disease. World J. Exp. Med. 5, 218-224. https://doi.org/10.5493/wjem.v5.i4.218.

Mirzajani, F., Askari, H., Hamzelou, S., Schober, Y., Römpp, A., Ghassempour, A. Spengler, B., 2014. Proteomics study of silver nanoparticles toxicity on Bacillus 
thuringiensis. Ecotox. Environ. Safe 100, 122-130. https://doi.org/10.1016/j. ecoenv.2013.10.009.

Moore-Landecker, E., 2002. Fungal spores. In: Encyclopedia of Life Sciences (eLS). John Wiley \& Sons Ltd., Chichester. https://doi.org/10.1038/npg.els.0000378.

Mueller, N.C., Nowack, B., 2008. Exposure modeling of engineered nanoparticles in the environment. Environ. Sci. Technol. 42 (12), 4447-4453. https://doi.org/ $10.1021 /$ es7029637.

Nair, P.M.G., Chung, I.-M., 2014. Cell cycle and mismatch repair genes as potential biomarkers in Arabidopsis thaliana seedlings exposed to silver nanoparticles. Bull. Environ. Contam. Toxicol. 92 (6), 719-725. https://doi.org/10.1007/ s00128-014-1254-1.

Navarro, E., Piccapietra, F., Wagner, B., Marconi, F., Kaegi, R., Odzak, N., Sigg, L., Behra, R., 2008. Toxicity of silver nanoparticles to Chlamydomonas reinhardtii. Environ. Sci. Technol. 42 (23), 8959-8964. https://doi.org/10.1021/es801785m.

Pascoal, C., Cássio, F., 2008. Linking fungal diversity to the functioning of freshwater ecosystems. In: Sridhar, K.R., Bärlocher, F., Hyde, K.D. (Eds.), Novel Techniques and Ideas in Mycology. Fungal diversity Press, Hong Kong, pp. 1-5.

Pascoal, C., Marvanová, L., Cássio, F., 2005. Aquatic hyphomycete diversity in streams of northwest Portugal. Fungal Divers. 19, 109-128.

Peterson, C.L., Côté, J., 2004. Cellular machineries for chromosomal DNA repair. Gene Dev. 18 (6), 602-616. https://doi.org/10.1101/gad.1182704.

Peterson, G.L., 1983. Determination of total protein. Method. Enzymol. 91, 95-121. https://doi.org/10.1016/S0076-6879(83)91014-5.

Petrak, J., Ivanek, R., Toman, O., Cmejla, R., Cmejlova, J., Vyoral, D., Zivny, J., Vulpe, C. D., 2008. Déjà Vu in Proteomics. A hit parade of repeatedly identified differentially expressed proteins. Proteomics 8 (9), 1744-1749. https://doi. org/10.1002/pmic.200700919.

Pradhan, A., Seena, S., Pascoal, C., Cássio, F., 2011. Can metal nanoparticles be a threat to microbial decomposers of plant litter in streams?. Microb. Ecol. 62 (1), 58-68. https://doi.org/10.1007/s00248-011-9861-4.

Pradhan, A., Seena, S., Schlosser, D., Gerth, K., Helm, S., Dobritzsch, M., Krauss, G.-J., Dobritzsch, D., Pascoal, C., Cássio, F., 2015. Fungi from metal-polluted streams may have high ability to cope with the oxidative stress induced by copper oxide nanoparticles. Environ. Toxicol. Chem. 34 (4), 923-930. https://doi.org/10.1002/ etc. 2879 .

Pradhan, A., Silva, C.O., Silva, C., Pascoal, C., Cássio, F., 2016. Enzymatic biomarkers can portray nanocuo-induced oxidative and neuronal stress in freshwater shredders. Aquat. Toxicol. 180, 227-235. https://doi.org/10.1016/j. aquatox.2016.09.017.

Rigbolt, K.T., Vanselow, J.T., Blagoev, B., 2011. GProX, a user-friendly platform for bioinformatics analysis and visualization of quantitative proteomics data. Mol Cell. Proteomics 10 (8), 0110.007450. doi:10.1074/mcp.0110.007450.

Santos, P.M., Simões, T., Sá-Correia, I., 2009. Insights into yeast adaptive response to the agricultural fungicide mancozeb: a toxicoproteomics approach. Proteomics 9 (3), 657-670. https://doi.org/10.1002/pmic.200800452.

Soares, H.M.V.M., Boaventura, R.A.R., Machado, A.A.S.C., Esteves da Silva, J.C.G., 1999. Sediments as monitors of heavy metal contamination in the ave river basin (Portugal): multivariate analysis of data. Environ. Pollut. 105 (3), 311 323. https://doi.org/10.1016/s0269-7491(99)00048-2.

Sondi, I., Salopek-Sondi, B., 2004. Silver nanoparticles as antimicrobial agent: a case study on E. coli as a model for Gram-negative bacteria. J. Colloid Interface Sci. 275 (1), 177-182. doi:10.1016/j.jcis.2004.02.012.

Tlili, A., Cornut, J., Behra, R., Gil-Allué, C., Gessner, M.O., 2016. Harmful effects of silver nanoparticles on a complex detrital model system. Nanotoxicology 10 (6), 728-735. https://doi.org/10.3109/17435390.2015.1117673.

van Aerle, R., Lange, A., Moorhouse, A., Paszkiewicz, K., Ball, K., Johnston, B.D., deBastos, E., Booth, T., Tyler, C.R., Santos, E.M., 2013. Molecular mechanisms of toxicity of silver nanoparticles in zebrafish embryos. Environ. Sci. Technol. 47 (14), 8005-8014. https://doi.org/10.1021/es401758d.

Vance, M.E., Kuiken, T., Vejerano, E.P., McGinnis, S.P., Hochella Jr., M.F., Rejeski, D. Hull, M.S., 2015. Nanotechnology in the real world: redeveloping the nanomaterial consumer products inventory. Beilstein J. Nanotechnol. 6, 17691780. https://doi.org/10.3762/bjnano.6.181.

Wang, P., Bouwman, F.G., Mariman, E.C., 2009. Generally detected proteins in comparative proteomics - a matter of cellular stress response?. Proteomics 9 (11), 2955-2966. https://doi.org/10.1002/pmic.200800826.

Yuan, Z., Li, J., Cui, L., Xu, B., Zhang, H., Yu, C.P., 2013. Interaction of silver nanoparticles with pure nitrifying bacteria. Chemosphere 90 (4), 1404-1411. https://doi.org/10.1016/j.chemosphere.2012.08.032.

Zhu, J.Y., Huang, H.Q., Bao, X.D., Lin, Q.M., Cai, Z.W., 2006. Acute toxicity profile of cadmium revealed by proteomics in brain tissue of Paralichthys olivaceus: potential role of transferrin in cadmium toxicity. Aquat. Toxicol. 78 (2), $127-$ 135. https://doi.org/10.1016/j.aquatox.2006.02.010. 